\title{
Varieties of Capitalism and the Euro Crisis
}

\section{Citation}

Hall, Peter A. 2014. "Varieties of Capitalism and the Euro Crisis." West European Politics 37 (6) (August 14): 1223-1243. doi:10.1080/01402382.2014.929352.

\section{Published Version}

doi:10.1080/01402382.2014.929352

\section{Permanent link}

http://nrs.harvard.edu/urn-3:HUL.InstRepos:17939585

\section{Terms of Use}

This article was downloaded from Harvard University's DASH repository, and is made available under the terms and conditions applicable to Open Access Policy Articles, as set forth at http:// nrs.harvard.edu/urn-3:HUL.InstRepos:dash.current.terms-of-use\#OAP

\section{Share Your Story}

The Harvard community has made this article openly available.

Please share how this access benefits you. Submit a story.

Accessibility 


\title{
Varieties of Capitalism and the Euro Crisis
}

\author{
Peter A. Hall
}

Minda de Gunzburg Center for European Studies

Harvard University

27 Kirkland Street

Cambridge MA 02138

Forthcoming in West European Politics 37/5 (2014)

\begin{abstract}
This article examines the role played by varieties of capitalism in the Euro crisis, considering the origins of the crisis, its progression and the response to it. Deficiencies in the institutional arrangements governing the single currency are linked to economic doctrines of the 1990s. The roots of the crisis are linked to institutional asymmetries between political economies. Northern European economies equipped to operate export-led growth models suitable for success within a monetary union are joined to southern economies whose demand-led growth models were difficult to operate successfully without the capacity to devalue. The response to a tripartite crisis of confidence, debt and growth is explained in terms of the interaction of institutions, interests and ideas, and its importance for the future of European integration is explored.
\end{abstract}


In Europe, the global debt crisis that began in 2008 appeared as a crisis of monetary union (EMU), which posed the most profound challenges confronting the European Union (EU) since the Treaty of Rome in 1958. This article examines the origins of the crisis and the response to it from a perspective that emphasizes the significance of differences in the organization of the European political economies. Economic prosperity in Europe has long been built on national varieties of capitalism, which condition the economic strategies pursed by governments and their comparative advantages (Hall and Soskice 2001; Hall 2001a; Amable 2003). Although many factors converged to produce this perfect storm, the Euro crisis reflects durable differences in political economies, whose import was largely unappreciated when EMU was designed and which have yet to be taken fully into account.

In the next section, I explore the origins of EMU and argue that deficiencies in its design are linked to economic doctrines that downplay the importance of the institutional infrastructure of the political economy. The second part examines the role played by national varieties of capitalism in the development of the crisis. The third interrogates the conventional view that the failure of the south to reform is the cause of the crisis, and the fourth explores the role that institutions, interests and ideas have played in the response to the crisis.

\section{The Design of EMU}

Many of the dilemmas facing Europe today flow from limitations in the institutions devised to administer the monetary union agreed in the Maastricht Treaty of 1992 and established in 1999. Barely two years after a triumphal celebration of its tenth anniversary, financial commentators began to criticize the Euro in such scathing terms that one wondered how such a monetary union 
could have been created in the first place. The answer turns partly on geo-politics but also on the influence of economic doctrines.

EMU was essentially a political project, motivated by the desire of national governments to escape the torturous inter-governmental negotiations that had accompanied the periodic need to renegotiate exchange rates within the preceding European monetary system established in 1979 (Eichengreen 1992a). Ten such realignments took place in the first half of the 1980s alone. In this respect, the move to EMU was intended to be a step away from political negotiation toward a more technocratic approach to policy. French governments, in particular, chafed under the dominant role of the German Bundesbank and hoped a new European central bank would be more congenial to their interests. But monetary union also offered Germany guaranteed markets in trading partners that would no longer be able to devalue against the Deutschmark.

German opinion was divided and the Bundesbank especially reluctant to agree, but German Chancellor Helmut Kohl, a committed European, along with President François Mitterrand of France presented monetary union as an arrangement that would bind a newlyunified Germany to Europe, ensuring French agreement to German unification (Száz 1999; Dyson 1994; Dyson and Featherstone 1997; Attali 1995; Genscher 1995). The price extracted by the Bundesbank was a Stability and Growth Pact (SGP) that put limits of 3\% on government deficits and $60 \%$ on the national debt of the member states.

Although monetary union was predominantly a product of prevailing conceptions of national interest, as momentum for it grew, attention turned to whether it was economically viable and in what institutional form. In this context, shifts in contemporary economic doctrine conditioned the shape the new Union was to take. The most relevant shift was one away from 
the Keynesian economics focused on active macroeconomic management, which had been influential since World War II but was discredited by its failure to cope with stagflation during the 1970s. By the end of the 1980s, Keynesian doctrines had been superseded by 'new classical' views of the economy underpinned by a rational expectations economics that saw little value in active macroeconomic management and located the roots of employment and growth on the supply-side of the economy (McNamara 1998). Mainstream economists began to think fiscal policy was rarely stabilizing and monetary policy had few lasting effects on the real economy. To promote growth, governments were advised to turn away from demand management toward policies designed to intensify competition on the supply side of the economy (Crystal 1979; Cuthbertson 1979).

The minimalist institutional structure of EMU was ultimately a reflection of the lowest common denominator on which the member states could agree. But that structure was seen as viable because of these shifts in economic doctrine. Policy-makers did not follow economic doctrines in lock-step fashion. After all, economists were divided on these issues and some argued that monetary union could not work without political union (cf. Eichengreen 2012). But, once the political desirability of union was agreed, prevailing doctrines influenced the shape its institutions would take. Since active fiscal policy was now deemed counterproductive, there was little pressure to give the Union institutional capacities for active coordination of fiscal policy beyond crude limits on national deficits and debt. Since monetary policy was widely seen as useful only for addressing inflation and best when based on rules, the new union was endowed with a European central bank (ECB) entirely independent of political control and forbidden from purchasing sovereign debt (Dyson and Featherstone 1997; McNamara 1998). The result was a 
highly technocratic arrangement in which issues once seen as politically demanding would be resolved by fixed rules and experts operating outside the political realm.

These doctrines ignored durable institutional differences across the political economies of the EU in favor of an image of the ideal economy as one built on classically-competitive markets operated by highly-informed actors, whose management would require only the minimal institutions with which the new union was endowed. Although policy-makers recognized that the European economies did not conform to this image, an element of prophecy was built into this mythology - when forced to compete under the discipline of a single market joined to a monetary union, Europe's economies were expected to converge on more competitive institutions (Hall 2001b). Of course, like previous convergence theories, this one proved overly optimistic. Entry into monetary union was not enough to erase the structural differences among Europe's political economies - and many of the problems EMU encountered have roots in those differences (Zeitlin et al. 2005).

\section{The Roots of the Euro Crisis}

Why did EMU experience a crisis severe enough to threaten its very existence barely a decade after its inauguration? A number of factors combined to imperil the union, including a decade of excessive lending and borrowing, which culminated in a global banking crisis that shook the confidence of financial markets around the world (Blyth 2013; Hall 2013). Plenty of mistakes by governments and firms added fuel to this fire. Greek governments took the country's deficits and debt to unsustainable levels. Like their American counterpart, the Irish and Spanish governments failed to dampen down housing booms that put their banking systems at risk. In many respects, this is a classic debt crisis: over-exuberant lending and borrowing built on 
inadequate regulation and unrealistic expectations about asset prices led to a recession in which much of this debt had to be written off (Reinhart and Rogoff 2009).

In Europe, however, this crisis has taken a form shaped by national varieties of capitalism. Serious problems were created by institutional asymmetries in the political economies of its member states (Boltho and Carlin 2012). In some cases, nationally-specific variations mattered, but many of the dilemmas stem from basic differences in the political economies of northern and southern Europe. To stylize slightly, on one side is a set of coordinated market economies in 'northern' Europe, operating export-led growth models built on high levels of wage coordination, sophisticated systems of vocational training, the inter-firm relations necessary to operate collaborative research and development, and intra-firm relationships that promote continuous innovation and quality control. These include the economies of Germany, the Netherlands, Belgium, Finland and Austria (Hall and Soskice 2001; Streeck 1992).

Another set of countries in 'southern' Europe might be described as mixed market economies where, apart from periodic 'social pacts', wage bargaining is difficult to coordinate because trade unions are relatively strong but vie with one another for the allegiance of the workforce and the right to negotiate wage bargains (Hancké 2013; Johnston et al. 2014). Employer associations are sometimes more coordinated, but they were less deeply institutionalized than their northern European counterparts and poorly-equipped to operate collaborative vocational training schemes. Partly for this reason, larger segments of the workforce are less skilled and continuous innovation is more difficult to achieve than in the north. Firms are correspondingly more inclined to build their competitive advantages on lowcost labor. With some notable variations across sectors and countries, the political economies of 
Greece, Spain, Portugal and Italy share these features (Glatzer 1999; Hall and Gingerich 2009; Iversen and Soskice 2014).

There are some distinctive features to each country and how the crisis developed there. In Greece, political patronage swelled the ranks of public employees and excessive public deficits precipitated the crisis. Budgetary deficits were moderate in Spain and Italy but labor productivity stagnated there, while lending to the private sector was a prominent problem in Portugal and Spain. Ireland stands apart as a liberal market economy that built a viable economic model on incentives for foreign direct investment and a social pact for wages, but its government allowed Irish banks to overextend their lending in the context of a construction boom. In broad terms, however, differences in the organization of the political economies of Europe's north and south stand out.

Moreover, the organizational structure of the political economy is nor ephemeral. It develops over long periods of time out of myriad political struggles and becomes fundamental to how firms organize their endeavors (Thelen 2004; Streeck and Yamamura 2001). While subject to incremental reform, including efforts to liberalize labor and product markets, the most basic features of the political economy, conditioning the capacities of firms and other actors to coordinate their endeavors, are relatively durable social facts, to which governments seeking prosperity and comparative advantage in international markets have to adjust their economic strategies, and historically that is what governments have done (Hall and Soskice 2001).

Thus, as Table One indicates, the governments of northern Europe have often taken advantage of the institutional capacities for coordination in their political economies to pursue strategies based on export-led growth, i.e. growth in which the expansion of exports is prominent 
relative to the expansion of domestic demand. Wage coordination restrained the rate of growth of unit labor costs, and para-public systems of skill formation were deployed to encourage high value-added production and the incremental innovation that allows firms to compete on quality as well as price. For the most part, such strategies dictate a neutral or moderate macroeconomic stance, because expansionary policy can set off wage-price spirals and counter-cyclical policy is less effective where a workforce with high levels of industry-specific skills prefers high savings ratios (Katzenstein 1985; Soskice 2007; Carlin and Soskice 2009).

Conversely, because their institutions are not conducive to export-led growth strategies, the governments of southern Europe have been more inclined to pursue demand-led growth, i.e. strategies based on the expansion of domestic demand. These entail more active macroeconomic policies, a focus on job creation in services and, in some cases, subsidies designed to create employment for low-skilled workers. Because expansionary macroeconomic policies tend to raise rates of inflation, in the years before EMU, many of those governments used periodic devaluations of their exchange rates to lower the price of exports and raise the price of imports, thereby off-setting the effects of inflation on the trade balance. The value of the Italian lira, for instance, declined by about 25 percent within six years after the establishment of the European monetary system in 1979.

Entry into EMU had different implications for these two types of political economies. The countries of northern Europe were well-placed to take advantage of membership in the new union. They could continue to pursue export-led growth strategies in a more favorable context in which their principal trading partners could no longer devalue to increase the competitiveness of their own products against those exports; and the Euro held down the external exchange rate, thereby enhancing the attractiveness of their exports in other markets. Based on serious efforts 
to contain wage rates, countries in northern Europe such as Germany began to build up large balance of payments surpluses inside the Eurozone.

For the political economies of southern Europe, however, EMU posed more serious challenges. Entry lowered some of their transaction costs and the convergence criteria in the run-up to monetary union initially strengthened the hand of governments seeking wage restraint. But entry into monetary union also called into question the viability of the demand-led growth strategies on which these countries had long relied, because they could no longer devalue to offset the accompanying inflation. Their governments had to decide whether to abandon demand-led strategies and, if so, in favor of what. As it happened, the decision was largely made for them by the unanticipated effects of EMU itself. The confidence effects generated by the new union quickly lowered the cost of capital in southern Europe; and, to invest the balance of payments surpluses building up in the north, the banks of northern Europe sent large flows of funds to southern Europe. Thus, even when the governments of the south did not adopt an expansionary fiscal stance, cheap credit fueled the expansion of domestic demand.

The effects were predictable, if largely unpredicted. With expansion came inflation, which took prices and relative unit labor costs in the south to new heights. Unable to devalue to offset the effect of such developments, those countries saw their current account balances deteriorate, as their products became less competitive on world markets, just as competition from the emerging economies of Asia and Eastern Europe intensified. In principle, the ECB could have used its monetary instruments to reduce rates of inflation in southern Europe, but doing so would have risked contraction in the north, where real interest rates were already higher. Instead, the ECB kept its eye on German wage settlements, which set the pattern for agreements in many other parts of northern Europe. 
The rest, as they say, is history. When the American bubble burst, shaking confidence in global financial markets, investors in European bonds became alarmed by the levels of debt present in Europe and more reluctant to fund southern European firms and governments, even in countries with public-sector deficits and debt lower than those of apparently creditworthy neighbors. For five years, the European Union has been trying to find a way to restore confidence in the financial markets and a route out of the deep recession experienced on its periphery.

\section{A Path Not Taken}

In hindsight, it is clear that some governments should have taken steps to dampen down asset booms in the early 2000s, although, in the context of a one-size-fits-all monetary policy, fiscal policy would have had to be unrealistically draconian to avert the balance of payments deficits building up in southern Europe (Carlin 2011). The second-order question is whether the governments of Greece, Ireland, Italy, Portugal and Spain (GIIPS) should have implemented more supply-side reforms in this decade. Did these countries waste their first decade in the Euro? Conversely, should the northern nations have operated more reflationary policies, thereby limiting the trade imbalances in the Eurozone, as some suggest?

In the realm of principle, anything is possible; but, in the realm of policy, what governments do is conditioned by what they learn from experience and the institutional incentives they have for pursuing various lines of policy. The popular contention that Germany could have averted the crisis by increasing domestic demand at a faster pace ignores fundamental features of the German political economy. Counter-cyclical fiscal policy has more limited effects there because the savings rates of workers with specific skills tend to increase during 
downturns, and expansionary fiscal policy can disrupt the wage restraint on which Germany's export performance has been built (Carlin and Soskice 2009). Indeed, after a decade in which massive spending to achieve reunification had reduced Germany's competitiveness, that country entered EMU at a high exchange rate and spent its first decade in monetary union making painful efforts to restrain the rate of growth of real wages so as to sustain its export-led growth model. Even today, there are doubts that German reflation would do much good (t’Veld 2013).

Similarly, any suggestion that the governments of southern Europe should have emulated the economic models of northern Europe is implausible: the lack the institutional infrastructure to do so. But did they do enough to reform the supply side so as to improve the efficiency of their economies? Southern European governments did take significant steps in this direction during the 2000s. On the OECD index for product market regulation, a good indicator for this sort of structural reform, the improvement in the south was roughly equivalent to that in the north, albeit from a higher base (see Table Two). Similarly, from a higher base, levels of employment protection declined faster in most of southern Europe than in the north (OECD 2004: Chart 2.2). The proportion of employees working under labor contracts of limited duration increased dramatically in many of these countries and some, such as Spain and Portugal, opened significant public monopolies up to private competition. The contention that southern European governments failed to implement reforms does not stand up to the evidence. Most still have significant insider-outsider divisions in their labor force, but so do France and Germany (Palier and Thelen 2010).

As the Greek case indicates, however, the Euro crisis stemmed from problems of political as well as economic development. A series of Greek governments took advantage of lower borrowing costs to expand wages in a public sector where political patronage was endemic 
(Featherstone 2012; Wade 2012; cf. Jones 2014). Economic modernization has been more difficult in regimes that were slow to modernize their public administrations. However, this is understandable. Until the middle of the 1970s, Spain and Portugal were ruled by authoritarian regimes, as was Greece between 1967 and 1974. Their new democratic governments took significant steps forward, but they could not rebuild state-society relations overnight; and, in order to mobilize consent for newly democratic regimes, they often left in place protections for privileged occupational groups (Glatzer and Rueschemeyer 2005; Royo 2014).

\section{The Response to the Crisis}

There is not space here to recount the history of the crisis in detail (for overviews see Baldwin et al. 2011; Marsh 2011). In 2009, revelations about the scale of Greek deficits touched off a sovereign debt crisis, and the IMF and EU bailed out Greece in return for deep budget cuts. Ireland was forced to accept European loans in exchange for fiscal austerity in November 2010, after its grossly-overextended banks failed when an asset boom collapsed (Hardiman 2012). A similar arrangement was made for Portugal in May 2011 and. under pressure from the bond markets and ECB, new governments in Spain and Italy adopted austerity programs, followed by a bailout of Spanish banks in the spring of 2012. In March 2013, a bailout program that imposed large losses on bank depositors was negotiated for Cyprus. The announcement of the ECB in September 2012 that it would offer unlimited support for the bonds of governments under pressure calmed the markets; but there are still plenty of dubious assets on the balance sheets of some European banks (Blyth 2013).

Three features of the response to the crisis are notable. First, there was a European response: under pressure from the bond markets, the countries of northern Europe provided 
hundreds of billions of Euros in loans to other countries. At roughly $€ 220$ billion by the end of 2012, the German contribution was equivalent to a full annual budget. However, the member states provided this support slowly and reluctantly: the European Financial Stability Fund (EFSF) was not ratified until October 2011, and its successor, the European Stability Fund (ESF), equipped with €500 billion and a longer-term remit, was not fully operational until 2013. Third, this strategy imposed the initial costs of adjustment disproportionately on the GIIPS, giving rise to economic misery in many parts of southern Europe. Greece was forced into one of the most draconian austerity programs in history, designed to reduce its budget deficit by 11 percentage points of GDP within three years. Alongside difficult structural reforms, Ireland was asked to reduce its budget deficit by 9 percentage points of GDP in five years, and Portugal by 6 percent within three years. For comparative purposes, note that the oil price shock of 1974 that ushered in a traumatic recession took roughly 4 percent out of European GDP.

By contrast, the initial costs of adjustment borne by the countries of northern Europe were relatively modest, although they are likely to rise in coming years. The aid given to the GIIPS came mainly in the form of loans that were supposed to be repaid; and the governmental contributions to the EFSF and ESM were largely guarantees for borrowing rather than direct transfers of funds. Since a large proportion of this aid was devoted to servicing the existing debts of the southern Europeans, the northern Europeans were essentially bailing out their own banks (see Table Three). As of 2012, for example, more than two thirds of the bailout funds transferred to Greece from the EFSF and IMF were being used to service existing debt, while barely a third was available for public spending (Alderman and Ewing 2012; Hall 2012).

How can the character of the response be explained and what does it reveal about the prospects for European integration? To answer these questions, it is useful to recognize that 
embedded within the Euro crisis are three distinct economic crises (Shambaugh 2012). At its outset, the crisis appeared as a crisis of confidence in the markets for sovereign debt. Behind this was a wider crisis of the European financial system, marked by a decade of overextended lending to in both the public and private sectors, fueled by asset booms. Since some of that debt cannot be repaid, this dimension of the crisis has called into question the solvency of many European financial institutions and inhibited cross-border flows of funds in Europe. The appearance of sharp differences in the price and availability of funds across the member states has turned the clock back on European financial integration: EMU now looks more like the old European monetary system. Finally, this has become a crisis of growth for Europe, marked initially by recession across the continent and then a bifurcation, as northern Europe begins to recover while southern Europe stagnates under the weight of heavy austerity programs. A pattern of continental dualization now mirrors the dual labor markets inside many European economies (Emmenger et al. 2012).

One of the best ways to understand the response to the crisis is to see it as a product of interactions between institutions, interests and ideas. The role played by the shape of European institutions is most evident. Addressing a debt crisis requires swift action to restore investor confidence, support for member governments that entails some redistribution of risks and funds across them, and ultimately decisions about who will be repaid and who will not. European institutions were not adequate to these challenges. The European central bank was explicitly forbidden by a 'no bailout' clause from direct purchases of sovereign debt or transfers of funds among the member states. As a technocratic institution without a political arm, it had no capacity to decide how financial support should be tied to budgetary conditions or to determine how the costs of the debt crisis were to be allocated. 
As a result, many of the key decisions had to be made by the other EU institutions, but they too were not designed for quick decision-making and unaccustomed to redistributing resources across the member states. Aside from a limited set of structural funds, which are largely side-payments to countries at lower levels of development, the European Union is not a redistributive enterprise, as its limited authority over social policy indicates (Leibfried and Pierson 1995; Majone 1996; Ferrera 2009). Moreover, on matters of central national interest, the core of European decision-making remains intergovernmental, and all the member governments must agree to any major moves (Moravcsik 1998). As a result, most of the major decisions bearing on the Euro crisis had to be taken in an endless succession of meetings involving heads of government.

Thus, despite the inventive efforts of the European central bank to provide liquidity troubled states and banks, the crisis of confidence in the bond markets dragged on because a key means of resolving such crises, in which the central bank guarantees investors will be repaid, if necessary via unlimited purchases of debt, was closed to the ECB. Only when the Bank finally used its mandate to promote free flows of funds to justify a program of 'outright monetary transactions' in September 2012 were the bond markets reassured that it would stand behind the credit of the member states. In the meantime, the protracted intergovernmental negotiations required to agree bailout programs eroded the confidence of investors.

It has been even more difficult for the EU to come to terms with the deeper issues generated by the crisis in the European financial system. A debt crisis arises when lending has increased to the point that some debts cannot be repaid. Thus, resolving it entails specifying who is going to be paid back and who is not. In the absence of a capacity to reach overarching agreement about such matters, the member states have temporized, lending funds to banks and 
governments on the assumption these would be repaid, even when the prospects of that are unlikely as in the case of Greece. This approach was taken partly in order to give European financial institutions time to cope with the non-performing loans on their balance sheets. In much the same way, the emergency liquidity measures of the ECB have kept financial institutions in southern Europe afloat, even though many have loans on their balance sheets that will never be repaid, but progress toward a banking union in which the Eurozone states would identify and take joint responsibility for those losses has been slow.

Small steps have been taken to allocate losses. Private investors in Greek sovereign debt were forced into a 'voluntary' restructuring program that imposed significant losses on them; and those holding assets in Cypriot banks bore heavy losses in that country's painful bailout program. Meanwhile, purchases of debt by the ECB and EFSF have transferred a good deal of the sovereign debt of southern Europe to public institutions, raising the prospects that this debt may eventually be restructured in ways that impose the relevant losses on the taxpayers of the member states. However, governments have not yet been willing to allocate such losses openly.

Here, the most fundamental problem is not institutional design but conflicts of interest among the member states. One of the striking features of the response to the Euro crisis has been the extent to which national governments have approached it as a problem that engages their short-term national interest rather than their collective interest in the EU. At every step, the European decision-making process has been marked by a struggle on the part of the member states to ensure that more of the risks and costs will be borne by other states. This is one reason why the full costs of the debt crisis have not yet been allocated. This dynamic is evident in the resistance of the Netherlands, Finland and Germany to allowing the ECB to purchase sovereign debt or transfer funds across national borders to stem the crisis of confidence in the financial 
markets. It appears in the glacial movement toward banking union, which has endowed the ECB with supervisory authority over large European banks but is still elusive on the issue of who will pay to wind down insolvent banks.

Conflicts of national interest have also left their mark on the EU's response to the growth crisis. Here the issue is how to restart economic growth on a continent still coming only slowly out of recession and how to restore prosperity, in particular, to the peripheral countries still suffering from levels of unemployment that run between 15 and 27 percent of the labor force. Ostensibly, the EU has a 'growth strategy' - built on two pillars. One is a commitment to balanced budgets reflected in the 'fiscal compact' of March 2012 whereby the member states agreed to legislate that mandate into their most basic laws. The second is a commitment to 'structural reform’ understood as measures designed to increase the intensity of competition in markets for labor and goods via privatization or deregulation.

But this growth strategy is a mirage. Neither of these steps is likely to inspire growth in southern Europe in the short to medium term. Even the IMF agrees that southern European rates of unemployment are likely to improve in the near term only if austerity is relaxed in favor of some reflation. Indeed, some countries' deficits are barely declining as a share of GDP, despite budget cuts, because those cuts are depressing GDP so much (Blanchard and Leigh 2013). Similarly, while structural reform might improve the efficiency of economies in the long-run, it is unlikely to promote economic growth in southern Europe in the short to medium term. European policy-makers know this but, because they have to have a growth strategy and are unable to agree on an alternative, they have pinned their hopes on structural reform. 
Is there an alternative? Two other strategies are conceivable. One would see the mixed market economies of southern Europe abandon the Euro in favor of floating exchange rates that might give them more room for demand-led growth over the long-run. But their governments are unenthusiastic about doing so because there is symbolic value to membership in the currency union and the short-term costs of leaving it would be enormous. Many of their financial institutions could fail and the immediate result would be even deeper recession. Northern European governments are struggling to preserve the Euro for parallel reasons. Break-up would see their exchange rates rise and competitiveness decline, and their taxpayers might have to absorb large losses on the lending already made to southern Europe (McKinsey Germany 2012).

Another alternative might be viable. It would involve some reflation in the southern European economies over the short term and a long-term development strategy, backed by substantial transfers from the north, to advance the sectors on which the capacities of the south to compete ultimately depend. The EU has taken preliminary steps on both fronts. The terms of various austerity programs are being relaxed slightly with a minimum of fanfare; and, in collaboration with the European Investment Bank, the Union has made small investments in the south. But a full-scale development program would require the member states to share responsibility for economic development within the Union as a whole on a scale far larger than existing regional transfers comprehend.

It is not difficult to see why this approach is unappealing to the governments of northern Europe. On the one hand, it would engage their resources in a strategy that is not guaranteed to succeed. The costly Italian efforts to inspire economic development in the Mezzogiorno provide a cautionary tale and it is not clear how many parts of southern Europe can develop a strong export base. A development strategy based on low-cost production is impractical given global 
competition from emerging markets; and moving up the value chain is a challenge for which there are no easy recipes. Embarking on such a program would require an act of faith on the part of northern European governments. On the other hand, the activist industrial intervention such a strategy would entail is inimical to the focus on market liberalization that has been the touchstone for European integration since the Single European Act of 1986; and relaxing austerity runs the risk of taking the immediate pressure for structural reform off southern European governments.

This is where prevailing ideas play important roles. The way forward depends on the overarching visions of Europe embraced by national governments and on the economic doctrines animating their policies. The presence of an overarching vision of Europe matters because it specifies why states should accept short-term risks or sacrifices in order to achieve long-term gains. This is a longstanding feature of the politics of European integration. The EU is only viable if it is seen as a positive-sum game. Since the European Economic Community in the 1950s, each of the major steps taken in the name of integration have entailed short-term sacrifices on the part of some member states that were acceptable because they could be presented as steps toward more substantial gains for all (Moravcsik 1998; Parsons 2003). In this respect, overarching visions of Europe underpin what the European Union can accomplish.

Jean Monnet underlined this when he declared that Europe must see itself as a common 'community of fate' - and for two decades after World War II European integration was motivated by a legitimating vision that saw its objective as peace in Europe and the means as economic integration. When that vision receded into memory, Europe found a new one, under the leadership of Jacques Delors and symbolized by the Single European Act of 1986, which held that deeper economic integration into a single market under a single currency would bring 
such long-term prosperity for all that it could justify any short-term sacrifices required to pave the way. In the wake of the Euro crisis, however, that vision is now in tatters. By its very nature, a debt crisis has zero-sum features: governments must allocate losses among creditors and debtors rather than apportion gains; and governments have exacerbated their dilemmas by presenting the problem as a debt crisis rather than a growth crisis. Many in southern Europe are beginning to ask on whose behalf are they now making sacrifices; and the emergence of bifurcated growth paths in Europe has made a hypothetical problem more real. Northern Europe is beginning to recover, while most of the South still stagnates. As a result, the promise of the EU to secure prosperity for all, founded on a vision of Europe's economic interdependence, has gradually dissolved, taking with it one of the pillars on which the legitimacy of European integration has been based.

The political dynamic at the heart of the response to the crisis has exacerbated this problem. When the crisis first hit, instead of presenting it as an existential challenge for the EU calling for pan-European solidarity, many politicians in the north portrayed it, not as a common crisis of the European financial system, but as a result of the fiscal fecklessness of southern governments, even though Germany and France were the first countries to violate the Stability and Growth Pact and public spending in countries such as Spain was relatively restrained. The European media was soon full of images of lazy Greeks, followed in the south by images of jackbooted Germans. This framing has made it much harder for governments in both the north and south to mobilize electoral consent for burden-sharing. At a popular level, the analogue to a common vision of Europe is some sense of shared social solidarity. But social solidarity now seems to stop at national borders (Pew Research Center 2012). In short, in the absence of a vision of an interdependent Europe capable of securing positive-sum outcomes through 
integration, it is not surprising that the member governments are giving much more priority to their short-term national interests; and the prospects for a continental program of economic development seem slim.

However, the ability of the member states to agree on such a program has also been impeded by longstanding differences in national economic doctrine. Economics is a transnational discipline marked by considerable agreement on its core heuristics, but national policy-makers have typically put more emphasis on some doctrines over others in ways that resonate both with national philosophies of governance and with varieties of capitalism (Schmidt 2008; Fourcade 2009). In this instance, these divergences have fueled disagreement both about the causes of the Euro crisis and how it should be resolved.

For illustrative purposes, consider the cases of Germany and France, two of the countries that must agree on a way forward. In Germany, many analysts and policy-makers have been deeply influenced by the doctrines of a Freiburg school of economics, which is focused on monetary stability, skeptical about the value of activist economic management, and inclined toward rule-based approaches to economic policy (Allen 2005; Kaltenthaler 1998, 2006). This perspective is conducive to a diagnosis that locates the causes of the crisis in the failure of governments to abide by the rules of the Stability and Growth Pact and sees the solution as a matter of strengthening such budgetary rules rather than reflating to restart growth.

German experience tends to confirm such views because prescriptions of this sort are well-suited to the management of a coordinated market economy focused on export-led growth, where budgetary restraint underpins wage coordination and many problems are resolved via negotiation among producer groups for which the government simply provides rules or 
'framework policies' within which such negotiations can take place (Casper 2001). There is resonance here too with the philosophies of governance that became prominent in post-war Germany, including an ordo-liberalism which holds that government should play only a 'steering' role in society, setting broad parameters for a 'social market economy' whose sources of dynamism lie in the private sector (Sally 1998). This philosophy has not prevented German governments from intervening forcefully in the economy from time to time; but its emphasis on addressing problems by promulgating rules has conditioned the approach taken by German policy-makers to the Euro crisis (Ziegler 1997).

By contrast, French economists have long been more supportive of activist economic intervention via macroeconomic or industrial policies (Fourcade 2009). This posture has roots in a dirigiste tradition that goes back to the influence of Keynesian views in France during the 1950s, if not to Colbert, and to the indicative planning process through which the economy was modernized during the 1950s and 1960s (Hall 1986; Rosanvallon 1989). This perspective continues to influence the views of French policy-makers about what policies are legitimate and effective; and echoes of it can be found in many parts of southern Europe (Culpepper et al. 2006: Levy 2009).

Once again, the influence of this approach owes something to France's economic experience rooted in the organization of its economy. For much of the post-war period, the decisions of an activist state were central to the coordination of wages and investment there. Influential minimum wage laws and the state's capacity to impose local wage bargains on entire sectors provided the kind of coordination that was negotiated by organized interests in Germany. For decades, industrial planners exercised considerable influence over flows of funds in the economy (Zysman 2004). With the dismantling of dirigisme during the 1980s and 1990s, France 
moved away from this model, but its imprint is still visible in many reports about the management of the French economy.

This approach is also consonant with the Republican philosophies underpinning governance in France and some parts of southern Europe. Born of the Jacobinism of the 1789 Revolution, those philosophies see producer groups as organizations that speak inevitably only for partial interests and the state as the sole guardian of the public interest (Hayward 1988; Dyson 2010). Therefore, the economy is perceived as an arena of competing actors who are unlikely to cooperate with one another unless impelled by the state to do so; and national economic success is seen as the responsibility of the state. That success is not the product of a purely private economy; it also depends on the strategic vision of policy-makers (Culpepper 2003; Levy 1999; 2006).

Thus, at successive stages in the Euro crisis, French leaders have argued for more a more activist European Union and for a relaxation in the terms of austerity imposed on southern Europe. From their perspective, the solutions to the crisis lie, not in the promulgation of more rules, but in the development of a more expansive European growth strategy. Like Delacroix's Liberty Leading the People, successive French leaders have taken up the banner of economic activism on the European stage, only to retreat in the face of German objections to such an approach. Of course, Germany's reluctance to endorse such moves is influenced by the fact that it might have to pay the largest portion of their costs; but, in a context where the effects of all measures are uncertain, these differences in how national policy-makers diagnose the problems and envision the solutions have limited what could be agreed. National policy-makers do not simply operate different varieties of capitalism; they also think about capitalism in different terms 


\section{Conclusion: From Economic to Political Crisis}

Asked how it felt to face Britain's endemic balance of payments crises in the 1960s, Prime Minister Harold Wilson is said to have replied that it is like standing there watching blood pour out of one's veins. Over the past four years, European governments have staunched the bleeding in their bond markets, and begun to distribute the costs of the debt crisis. But much remains to be done, notably to allocate gains and losses in the European financial system and to cope with a growth crisis, especially in countries where up to a quarter of the workforce remains unemployed.

As a result, economic crisis has given rise to a political crisis, threatening the electoral prospects of national governments as well as the legitimacy of the European Union. A Greek government elected in 2012 holds onto a bare legislative majority, while the electorate drifts toward parties that reject austerity but provide no viable alternative to it. The 2013 elections in Italy gave parties opposed to austerity a majority of the vote, if not of legislative seats, making it difficult for successive governing coalitions to implement durable economic reforms. In Spain, the crisis has fueled Catalan nationalism and splintered the political right; while, in Ireland, the political fortunes of Sinn Fein have risen, as have those of the Front National in France. If there is no revival of growth in southern Europe over the medium term, it is unclear whether their electorates will continue to produce governments capable of sustaining the austerity policies agreed with the EU or what the EU will do if they cannot.

By and large, the answer would seem to be that the EU will muddle through, adjusting its policies at the margin to cope with new contingencies as they arise, much as it has over the past five years (Lindblom 1959). Austerity is already being relaxed around the edges and it is likely 
that Greek debt will be restructured, at some cost to the creditor states, much as Ireland's promissory notes were in February 2013 (Mabbett and Schelkle 2014). The rhetorical fig leaf placed over the crisis is a call for 'more Europe' on which most governments seem to agree. But agreement on that principle masks deep disagreement about what 'more Europe' Some national leaders suggest that 'more Europe' means a fiscal compact with stricter rules on debt and deficits, while others seem to hope it will entail a more aggressive form of transnational Keynesianism, if not something tantamount to European economic governance.

Ambiguities of this sort have their political uses but, in this case, they mask a more profound legitimacy crisis that calls into question what the EU can expect to achieve in the coming years. The most visible expression of that crisis is a growing Euro-skepticism evident in the European electoral arena, where Euro-skeptical parties are making serious inroads. National majorities continue to favor membership in the European Union, but support for some its core principles, such as free movement across European borders, is declining; and it has become harder for ordinary people, as well as observers, to discern just what the European Union stands for; a sauve-qui-peut strain is seeping into its politics at both the national and transnational levels.

Behind this politics lies a more profound institutional breakdown, reminiscent of Europe's experience during the economic crisis of the 1970s. At that time, rising rates of inflation reflected a breakdown in the capacity of the industrial relations institutions charged with allocating resources between capital and labor (Goldthorpe 1978). The ultimate result was a 'move to the market' that reorganized industrial relations and reduced the influence of trade union confederations across Europe. For the EU today, the issue is whether it has or can acquire the institutional capacities to allocate resources across Europe in terms that are capable of 
ensuring prosperity for all. At its heart, that is what the debate about 'more Europe' is really about and it is far from resolved. Politicians are calling for that, but mass electoral support for giving the EU more authority is declining, in northern as well as southern Europe (Pew Research Center 2012).

In this context, the political precondition for progress is the development of a new vision for Europe, specifying what interdependence requires and what collective action can deliver. European leaders have to decide again whether Europe is truly a common community of fate in which more generous support for the south is intrinsic to the well-being of the north or a set of nations whose economic fortunes are separate enough to merit only minimal transnational coordination without redistribution. If they choose the former, they will have to mobilize political consent for that path, but, if they choose the latter, they must find ways of avoiding a decade of deflation across the south and political effects analogous to those that followed efforts to sustain the gold standard (Polanyi 1944; Eichengreen 1992b; Simmons 1997).

Thus, monetary union has brought the European Union to a crossroads in which its leaders are being asked to reconsider the European project once again. This analysis suggests that, in order to do so successfully, they will have to abandon the demand that the countries of southern Europe emulate the economic models of the north, as if there were only one way to run a successful economy (Evans 2004). This was the lesson the authors of the post-war economic order took from inter-war experience. Instead of insisting on a single pattern of policy, they designed transnational institutions flexible enough to support multiple social and economic models (Ruggie 1982). National distinctiveness was not seen as inimical to international solidarity. The motto of the EU is not 'uniformity' - but 'unity in diversity' - and the future of European integration will depend on Europe’s capacity to give substance to that slogan. 


\section{Acknowledgments}

I am grateful to Pepper Culpepper, Philipp Genschel and Randall Hansen for comments on an earlier draft.

\section{References}

Alderman Liz and Jack Ewing. (2012). 'Most Aid to Athens Circles Back to Europe,' New York Times (29 May).

Allen. Christopher.S. (2005). 'Ordo-Liberalism Trumps Keynesianism: Economic Policy in the Federal Republic of Germany'. In B. Moss, ed., Monetary Union in Crisis: The European Union as a Neo-Liberal Construction. London: Palgrave, 2005, pp. 199-221

Amable, Bruno (2003). The Diversity of Modern Capitalism. Oxford: Oxford University Press.

Attali, Jacques (1995). Verbatim: Tome 3. Chronique des Années 1981-1991. Paris: Fayard 1995.

Baldwin, Robert, Daniel Gros and L. Laeven eds. (2011). Completing the Eurozone Rescue: What More Needs to be Done? London: Center for Economic Policy Research.

Blanchard, Olivier and Daniel Leigh (2013). 'Growth Forecast Errors and Fiscal Multipliers.' Washington DC: IMF Working Paper.

Blyth, Mark (2013). Austerity: The History of a Dangerous Idea. New York: Oxford University Press.

Boltho, Andrea and Wendy Carlin (2012).'The Problems of European Monetary Union: Asymmetric Shocks or Asymmetric Behaviour?’ http://www.voxeu.org/article/problems-eurozone

Wendy Carlin (2011). 'Real Exchange-Rate Adjustment, Wage-Setting Institutions and Fiscal Stabilization Policy: Lessons of the Eurozone's First Decade,' CESifo Economic Studies (2011): doi: 10.1093/cesifo/ifs025

Carlin Wendy and David Soskice (2009). 'German Economic Performance: Disentangling the Role of Supply-Side Reforms, Macroeconomic Policy and Coordinated Economy Institutions,' Socio-Economic Review 7: 69-99

Casper, Stephen (2001). 'The Legal Framework for Corporate Governance: The Influence of Contract Law on Company Strategies in Germany and the United States.' In Peter.A. Hall and David Soskice, eds. Varieties of Capitalism. Oxford: Oxford University Press, 337-60.

Conway, Paul, Véronique Janod and Giuseppe Nicoletti (2005). 'Product Market Regulation in OECD Countries 1998-2003,” OECD Economics Department Working Papers No. 419. Paris: OECD.

Crystal, Alec (1979). Controversies in British Macroeconomics London: Philip Alan.

Culpepper, Pepper D. (2003). Creating Cooperation: How States Develop Human Capital in Europe. Ithaca: Cornell University Press.

Culpepper, Pepper D., Peter A. Hall and Bruno Palier. (2006). Changing France: The Politics that Markets Make. Houndsmills: Palgrave Macmillan. 
Cuthbertson, Keith (1979). Macroeconomic Policy: The New Cambridge, Keynesian and Monetarist Controversies. London: Macmillan.

Dyson, Kenneth (1994). Elusive Union: The Process of Economic and Monetary Union in Europe London: Longman 1994.

Dyson, Kenneth (2010). The State Tradition in Western Europe. NY: Columbia University Press.

Dyson, Kenneth and Kevin Featherstone (1997). The Road to Maastricht: Negotiating Economic and Monetary Union. Oxford: Oxford University Press.

Eichengreen, Barry (1992a). 'Should the Maastricht Treaty Be Saved?' Princeton Studies in International Finance, 74 (December).

Eichengreen, Barry (1992b) Golden Fetters: The Gold Standard and the Great Depression 1919-39. Oxford: Oxford University Press.

Eichengreen, Barry (2012). 'European Monetary Integration with Benefit of Hindsight,' Journal of Common Market Studies 50:S1, 123-36.

Emmenger, Patrick, Silja Häusermann, Bruno Palier and Martin Seeleib-Kaiser, eds. (2012). The Age of Dualization. Oxford: Oxford University Press.

Evans, Peter (2004). 'Development as Institutional Change: The Pitfalls of Monocropping and the Potentials of Deliberation,' Studies in Comparative International Development 38:4, 30-52.

Ferrera, Maurizio (2009). 'National Welfare States and European Social Policy: In Search of a Virtuous Nesting,’ Journal of Common Market Studies 47:2, 219-33.

Featherstone, Kevin (2012). 'The Greek Sovereign Debt Crisis: A Failing State in a Skewed Regime,' Journal of Common Market Studies, 49:2, 193-217.

Fourcade, Marion (2009). Economists and Societies: Discipline and Profession in the United States, Britain and France, 1890s to 1990s. Princeton, Princeton University Press.

Genscher, Hans-Dieter (1995). Erinnerungen Berlin: Siedler.

Glatzer, Miguel (1999). 'Rigidity and Flexibility: Patterns of Labour Market Policy Change in Portugal and Spain, 1981-96.' South European Society and Politics, 4(3).

Glatzer, Miguel and Dietrich Rueschemeyer. (2005). Politics Matters: Globalization and the Future of the Welfare State, Pittsburgh: University of Pittsburgh Press.

Goldthorpe, John A. (1978). 'The Current Inflation: Towards a Sociological Analysis', in. John A. Goldthorpe and Fred Hirsch, eds. The Political Economy of Inflation. Cambridge, MA: Harvard University Press, 186-213.

Hall, Peter A. (1986). Governing the Economy. Cambridge: Polity Press.

Hall, Peter A. (2001a). 'Organized Market Economies and Unemployment in Europe: Is it Finally Time to Accept Liberal Orthodoxy? ' in Nancy Bermeo, ed., Unemployment in the New Europe. New York: Cambridge University Press: 52-86. 
Hall, Peter A. (2001b). ‘The Evolution of Economic Policy’. In A. Guyomarch, H. Machin, P.A. Hall and J. Hayward, eds., Developments in French Politics 2, London: Palgrave: 172-91.

Hall, Peter A. (2012). ‘The Economics and Politics of the Euro Crisis’. German Politics:

Hall, Peter A. (2013). 'The Political Origins of our Economic Discontents: Contemporary Adjustment Problems in Historical Perspective.' In M. Kahler and D. Lake, eds. Politics in New Hard Times. Ithaca: Cornell University Press.

Hall, Peter A. and Daniel.W. Gingerich (2009). 'Varieties of Capitalism and Institutional Complementarities in the Political Economy: An Empirical Analysis'. British Journal of Political Science 39: 449-482

Hall, Peter .A. and David Soskice, eds. (2001). Varieties of Capitalism: The Institutional Foundations of Comparative Advantage. Oxford: Oxford University Press.

Hancké, Bob (2013). Unions, Central Banks and EMU: Labour Market Institutions and Monetary Integration in Europe. Oxford: Oxford University Press.

Hardiman, Niamh ed. (2012). Irish Governance in Crisis. Manchester: Manchester University Press.

Hayward, Jack E.S. (1988). Governing France: The One and Indivisible French Republic. $2^{\text {nd }}$ ed. London: Weidenfeld and Nicolson.

Iversen, Torben and David Soskice (2014). "A Structural-Institutional Explanation of the Eurozone Crisis.” Ms.

Johnston, Alison, Bob Hancké and Sami Pant. (2014). 'Comparative Institutional Advantage in the European Sovereign Debt Crisis,' Comparative Political Studies: 1-30.

Jones, Erik. (2014). “Competitiveness and the European Financial Crisis.” Paper presented to the International Conference of Europeanists, Washington, DC, March 15.

Kaltenthaler, Karl (1998). Germany and the Politics of Europe's Money Durham: Duke University Press, 1998.

Katltenthaler, Karl ( 2006). Policy-Making in the European Central Bank: The Masters of Europe's Money. New York: Rowman and Littlefield.

Katzenstein, Peter (1985). Small States in World Markets. Ithaca: Cornell University Press.

Leibfried, Stefan and Paul Pierson (1995). European Social Policy: Between Fragmentation and Integration. Washington DC: Brookings.

Levy, Jonah (1999). Tocqueville’s Revenge: State, Society and Economy in Contemporary France. Cambridge, MA: Harvard University Press.

Levy, Jonah ed. (2006). The State after Statism. Cambridge, Ma: Harvard University Press.

Lindblom, Charles (1959). 'The Science of ‘Muddling Through', Public Administration Review 19:2 7988. 
Mabbett, Deborah and Waltraud Schelkle (2014). 'Searching under the Lamp-Post: The Evolution of Fiscal Surveillance.' Paper presented to the International Conference of Europeanists, Washington, DC. March.

Majone, Giandomenico (1996). Regulating Europe. London: Routledge.

Marsh, David (2011). The Euro: The Battle for the New Global Currency New Haven: Yale University Press.

McKinsey Germany. (2012). The Future of the Euro. McKinsey \& Co.

McNamara, Kathleen (1998). The Currency of Ideas. Ithaca: Cornell University Press.

Moravcsik, Andrew (1998). The Choice for Europe: Social Purpose and State Power from Messina to Maastricht. Ithaca: Cornell University Press.

OECD (2004). Employment Outlook.

Palier, Bruno and Kathleen Thelen (2010). 'Institutionalizing Dualism: Complementarities and Change in France and Germany,' Politics \& Society 38:1, 119-148

Parsons, Craig (2003). A Certain Idea of Europe. Ithaca: Cornell University Press.

Pew Research Center (2012). European Unity on the Rocks. Washington: Pew Research Center.

Perez, Sofia (1998). Banking on Privilege: The Politics of Spanish Financial Reform Ithaca: Cornell University Press.

Polanyi, Karl (1944). The Great Transformation. Boston: Beacon Press.

Reinhart, Carmen M. and Kenneth.S. Rogoff (2009). This Time is Different: Eight Centuries of Financial Folly. Princeton: Princeton University Press.

Rosanvallon, Pierre (1989). ‘The Development of Keynesianism in France.’ In. P.A. Hall, ed., The Political Power of Economic Ideas: Keynesianism across Nations. Princeton: Princeton University Press, 171-94.

Royo, Sebastian (2008). Varieties of Capitalism in Spain: Remaking the Spanish Economy for the New Century New York: Palgrave.

Royo, Sebastian (2014). 'Institutional Degeneration and the Economic Crisis in Spain.’ Paper presented to the International Conference of Europeanists, Washington DC, March.

Ruggie, John (1982). 'International Regimes, Transactions, and Change: Embedded Liberalism in the Postwar Economic Order,’ International Organization 36(2): 379-415.

Sally, Razeen (1998). Classical Liberalism and International Economic Order. London: Routledge.

Schmidt, Vivien (2008). 'Discursive Institutionalism: The Explanatory Power of Ideas,' Annual Review of Political Science 11,303-26.

Shambaugh, J. C. (2012). 'The Euro’s Three Crises,' Brookings Papers on Economic Activity (Spring).

Simmons, Beth (1997). Who Adjusts? Domestic Sources of Foreign Economic Policy. Princeton:

Princeton University Press. 
David Soskice (2007). 'Macroeconomics and Varieties of Capitalism.' In Bob Hancké, Martin Rhodes and Mark Thatcher, eds., Beyond Varieties of Capitalism. Oxford: Oxford University Press, 89-121.

Streeck, Wolfgang (1992). Social Institutions and Economic Performance. Beverly Hills: Sage.

Streeck, Wolfgang and Kozo Yamamura, eds. (2001). The Origins of Non-Liberal Capitalism: Germany and Japan in Comparison. Ithaca: Cornell University Press.

Szász, André (1999). The Road to European Monetary Union Houndsmills, Basingstoke: Macmillan.

Thelen, Kathleen (2004). How Institutions Evolve. New York: Cambridge University Press.

Tilford, Simon (2010). 'How to Save the Euro.' Centre for European Reform Essays. (September.

t’Veld, Jan in (2013). 'Fiscal Consolidations and Spillovers in the Euro Area Periphery and Core,' European Economy Economic Papers (506). European Commission.

Vines, David (2010). 'Fiscal Policy in the Eurozone After the Crisis.' Paper presented at the MacroEconomy Research Conference, Tokyo.

Wade, R. (2012). 'Greece: Breaking the Doom Loop,' Le Monde Diplomatique (6 July).

Zeitlin, J., P. Pochet and L. Magnusson (2005). The Open Method of Coordination in Action. Brussels: Peter Lang.

Ziegler, Nicholas (1997) Governing Ideas: Strategies for Innovation in France and Germany. Ithaca: Cornell University Press.

Zysman, John (1984). Governments, Markets and Growth. Ithaca: Cornell University Press. 
TABLE 1

Varieties of Capitalism and Export Dependence (2007)

Exports \% GDP

Trade Surplus \% GDP

Coordinated Market Economies

Austria

Belgium

Denmark

Finland

Germany

Netherlands

Norway

Switzerland

$\underline{\text { Mixed }}$

France

Greece

Ireland

Italy

Portugal

Spain

$\underline{\text { Liberal Market Economies }}$

Australia

37

29

29

11

New Zealand

United Kingdom

United States
Sweden

5

4

3

5

6

8

17

8

8

$-1$

$-11$

10

0

$-9$
20

$-6$

26

$-1$

3

$-1$

$-3$

$-6$

Source: OECD, courtesy of John Stephens 
TABLE 2

Improvement in product market regulation 1998-2003

\begin{tabular}{|c|c|c|c|}
\hline & $\begin{array}{l}\text { PMR } \\
1998\end{array}$ & $\begin{array}{l}\text { PMR } \\
2003\end{array}$ & Improvement \\
\hline France & 2.5 & 1.7 & 0.8 \\
\hline Germany & 1.9 & 1.4 & 0.5 \\
\hline Netherlands & 1.8 & 1.4 & 0.4 \\
\hline Ireland & 1.5 & 1.1 & 0.4 \\
\hline Italy & 2.8 & 1.9 & 0.9 \\
\hline Portugal & 2.1 & 1.6 & 0.5 \\
\hline Spain & 2.3 & 1.6 & 0.7 \\
\hline
\end{tabular}

Source: Author's calculations based on Conway et al. 2005. 
TABLE 3

Southern European debt held by banks in the core of the Eurozone

(€ billions)

\begin{tabular}{|c|c|c|c|}
\hline & 1999 ( $\left.4^{\text {th }} Q\right)$ & $2009\left(4^{\text {th }} Q\right)$ & $\%$ Change \\
\hline Portugal & 26 & 110 & $320 \%$ \\
\hline Ireland & 60 & 348 & $481 \%$ \\
\hline Greece & 24 & 141 & $491 \%$ \\
\hline Spain & 94 & 613 & $554 \%$ \\
\hline Italy & 259 & 822 & $217 \%$ \\
\hline Total & 463 & 2033 & $340 \%$ \\
\hline
\end{tabular}

EZ Core is Ger, Fr, Au, Be, Neth.

Source: Baldwin et al. 2010. 